\title{
Short- and Long-Term Effects of Weaning Age on Pig Innate Immune Status
}

\author{
Janeen L. Salak-Johnson ${ }^{1,2 *}$, Sherrie R. Webb ${ }^{1}$ \\ ${ }^{1}$ Department of Animal Sciences, University of Illinois, Urbana, USA \\ ${ }^{2}$ Current Address: Department of Animal Science, Oklahoma State University, Stillwater, USA \\ Email: *janeen.johnson@okstate.edu
}

How to cite this paper: Salak-Johnson, J.L. and Webb, S.R. (2018) Short- and LongTerm Effects of Weaning Age on Pig Innate Immune Status. Open Journal of Animal Sciences, 8, 137-150. https://doi.org/10.4236/ojas.2018.82010

Received: February 25, 2018

Accepted: April 9, 2018

Published: April 12, 2018

Copyright (c) 2018 by authors and Scientific Research Publishing Inc. This work is licensed under the Creative Commons Attribution International License (CC BY 4.0).

http://creativecommons.org/licenses/by/4.0/

(c) (i) Open Access

\begin{abstract}
The study was conducted to evaluate short- and long-term effects of pig wean age on innate immunity and cortisol. Seventy-two white crossbred pigs from 12 litters were randomly assigned to a weaning age of 14 or $28 \mathrm{~d}$-of-age. Pigs were weaned at assigned treatment age and kept as littermates until 20 wk-of-age. Blood samples were taken prior to weaning ( $\mathrm{d} 0$ ) and days 1,7 , and 14 post-weaning (short-term), and at $8,12,16$, and 20 wk-of-age (long-term). Prior to weaning ( $\mathrm{d} 0$ ), total WBC and lymphocyte numbers were greater for 28-d weaned pigs than 14-d and 28-d pigs had greater lymphocyte numbers at $\mathrm{d} 1,7$, and 14 post-weaning. At $\mathrm{d} 0$, cytotoxicity and phagocytosis were greater for 14-d than 28-d weaned pigs. Regardless of age, at $d 1$ and 7 post-weaning all pigs had greater WBC counts, neutrophils, and phagocytosis, but reduced lymphocytes and NK cytotoxicity compared with $\mathrm{d} 0$. Cortisol was decreased at $\mathrm{d} 7$ and increased at $\mathrm{d} 14$ post-weaning in 28 - $\mathrm{d}$ weaned pigs. These pigs also had greater cortisol at d 0,1 and 14 post-weaning than 14-d weaned pigs. Effects of weaning on leukocyte profile and N:L ratio were longer-lasting in 14-d weaned pigs than 28 -d with effects still apparent at d 14 post-weaning for lymphocytes, neutrophils, N:L ratio, NK, phagocytosis, and IgG. These data imply that weaning age differentially affected pig leukocyte populations and innate immunity in response to weaning stress in both short- and long-term. More specifically, pigs weaned at $14 \mathrm{~d}$-of-age had a more profound and longerlasting stress response to weaning and 14- $\mathrm{d}$ weaned pigs had a more profound innate response, especially NK cytotoxicity while 28 -d weaned pigs had more profound antibody response (IgG) in the long-term and these responses were still evident at 20 wk-of-age.
\end{abstract}

\section{Keywords}

Age, Immune, Pigs, Stress, Wean 


\section{Introduction}

Weaning is a common stressful event in the life of a pig that involves abrupt social, nutritional, and environmental aspects, which may lead to low feed intake, weight loss, increased mortality and potentially compromised health. Various factors such as sex, age, previous experience, and genetics, just to name a few, can influence the stress responsiveness of an animal and the biological consequences [1]. Weaning age of a pig can impact the immune system and cortisol [2] [3] [4], but with variable results. Newly weaned pigs, especially those weaned prior to $20 \mathrm{~d}$-of-age are more vulnerable to disease [5] [6]. In fact, pigs weaned at 16 or $18 \mathrm{~d}$-of-age had more rapid onset of diarrhea to an $E$ coli challenge than pigs weaned at $20 \mathrm{~d}$-of-age [7]. Early-weaned pigs had increased neutrophilto-lymphocyte ratio-indicative of acute stress [8], decreased cellular immunity [9] and cytokine production [10], while pigs weaned at $>21 \mathrm{~d}$-of age had increased cortisol and decreased lymphocyte proliferation [11]. Still, others have found no effect of age at weaning on the immune system of pigs, including adaptive immunological competence [12] [13]. However, it has been shown that as weaning age progresses, the immune system develops, such that leukocyte populations shift from cells predominately involved in innate immune function at $14 \mathrm{~d}$-of-age to cells predominately involved in adaptive immune function at 21 and $28 \mathrm{~d}$-of-age implying that weaning age had short-term effects on endocrine and immune measures in pigs [14]. There is limited scientific information on effects that weaning age may have on immune responsiveness of the pig beyond the weanling phase. Therefore, the objectives of this study were to identify and describe the short- and long-term impacts of age at weaning on stress responsiveness and immune status of the pig.

\section{Materials and Methods}

\subsection{Animals and Experimental Design}

Seventy-two piglets were used from multiparous white-cross sows housed at the University of Illinois research farm (Urbana, IL). Six pigs per litter ( $\mathrm{n}=12$ litters) were randomly assigned to a weaning-age treatment of either 14 or $28 \mathrm{~d}$. At the assigned weaning age, 3 barrows and 3 gilts per litter were randomly assigned to a pen within a mechanically-ventilated and environmentally controlled animal house until 20-wk-of-age. The piglets chosen from each litter were balanced for body weight within sex. All pigs were fed a diet formulated to meet or exceed recommended nutrient allowances (NRC, 2000) and each pen was equipped with a cup waterer. The University of Illinois Institutional Animal Care and Use Committee approved all experimental procedures involving animals

\subsection{Blood Collection}

Blood sample were obtained at respective weaning age (14 or 28), and at $d 1,7$, and 14 post-weaning, and then again at $8,12,16$, and 20 wk-of-age. Blood sam- 
ples were collected via anterior vena cava puncture using vacutainers containing sodium heparin and samples were placed immediately on ice. Pigs were held in a supine position (procedure lasted $\leq 1 \mathrm{~min}$ ) until 8 wk-of-age, and then at 12 wk-of-age, pigs were nose-snared and sample was collected while the pig was standing (procedure lasted $\leq 2 \mathrm{~min}$ ).

\subsection{Cell Isolation and Counting}

Heparin-treated whole blood $(10 \mu \mathrm{l})$ was added to Isoflow (10 ml; Beckman Coulter, Miami, FL), red blood cells were lysed, and total white blood cell (WBC) counts were measured electronically using a Coulter Z1 Particle Counter (Beckman Coulter). Leukocyte differentials were made and manually counted using a light microscope to determine percentages of leukocyte cell populations. Whole blood was diluted with Roswell Park Memorial Institute (RPMI) medium (Gibco, Carlsbad, CA), layered over Hisptopaque-1077 (density: 1.077 g/ml; Sigma) and -1119 (density: $1.119 \mathrm{~g} / \mathrm{ml}$; Sigma), and centrifuged at $700 \times \mathrm{g}$ for 30 $\min$ at $25^{\circ} \mathrm{C}$. Lymphocytes were collected from the Hisptopaque-1077 layer, washed twice in RPMI, resuspended, and counted. Neutrophils and red blood cells were removed from the Hisptopaque-1119 layer and washed once in RPMI. Red blood cells were lysed using cold endotoxin-free water, and isotonicity was restored using 10× PBS. Neutrophils were centrifuged for $10 \mathrm{~min}$ at $475 \times \mathrm{g}$, supernatant was decanted, and the pellet was washed twice and resuspended in RPMI. Cell concentrations were adjusted with RPMI based on immune-assay requirements.

\subsection{Immune Assays}

Natural killer cell (NK) cytotoxicity was measured using a commercially available non-radioactive cytotoxicity-detection kit (Roche Diagnostics, Indianapolis, IN) as previously described [15]. Briefly, porcine lymphocytes were used as effector cells; K-562 chronic human myelogenous leukemia cells (American Tissue Type Culture Collection, Manassas, VA) as target cells. Lymphocytes were adjusted to $1 \times 10^{7}$ cells $/ \mathrm{ml}$ and K562 cells to a constant 10,000 cells per well. Samples were analyzed in triplicate at effector (lymphocytes): target-cell (K-562) ratios of 12.5:1, 25:1, 50:1, and 100:1, respectively. Results were measured using a microplate reader (BIO-TEK Instruments) at wavelength $490 \mathrm{~nm}$ and reference wavelength $690 \mathrm{~nm}$. Assay was considered valid if maximum release divided by spontaneous release was $\leq 20 \%$.

Neutrophil chemotaxis was measured using an assay previously described [16]. Briefly, neutrophils were used at a concentration of $3 \times 10^{6}$ cells $/ \mathrm{ml}$ to evaluate the ability of cells to migrate toward assay medium (control; random migration) or recombinant human complement-5a (hC5a; $10^{-7} \mathrm{M}$; Sigma) (chemotaxis; directed migration). Neutrophil phagocytosis was measured using a flowcytometry-based assay as previously described [17] with minor modifications [14]. Fluorescent beads were pre-incubated $30 \mathrm{~min}$ with non-heat-inactivated 
porcine serum before beads were added to samples at a 10:1 (beads-to-neutrophils) ratio. Cells and beads were incubated together for $45 \mathrm{~min}$, and then percentage of engulfment of fluorescent beads by cells was evaluated by means of a flow cytometer.

\subsection{Plasma Analyses}

Total plasma immunoglobulin $\mathrm{G}$ (IgG) was measured using an ELISA as previously described by Niekamp et al. (2007). Porcine plasma samples were diluted 1:3000 in $0.05 \%$ Tween-PBS. In duplicate, $120 \mu \mathrm{l}$ of diluted sample or standard was added to 96-well microtiter plates coated with porcine IgG (Jackson Immunoresearch, West Grove, PA). Rabbit anti-pig IgG (120 $\mu$; Sigma, St. Louis, MO) was added and plates were incubated for $2 \mathrm{~h}$ at $25^{\circ} \mathrm{C}$ and then washed three times with $0.05 \%$ Tween-PBS. Enzyme-linked anti-rabbit IgG $(200 \mu$ l; Jackson Immunoresearch) was added at a dilution of 1:7500. Plates were incubated for 1 $\mathrm{h}$, decanted, and then washed three times. Substrate solution $(200 \mu \mathrm{l} ; 1 \mathrm{mg} / \mathrm{ml}$ of p-nitrophenyl phosphate; Sigma) was added and, after 30-min incubation, the reaction was stopped with $100 \mu \mathrm{l}$ of $2 \mathrm{MNaOH}$. Plates were read using a microplate reader (Bio-Tek Instruments, Winooski, VT) at a wavelength $405 \mathrm{~nm}$. A standard curve $(0,0.1,0.5,1,5,10,20$, and $40 \mu \mathrm{g} / \mathrm{ml}$ of $\operatorname{IgG})$ was used to estimate total plasma IgG. Plasma cortisol was measured using a commercially available RIA kit (Coat-A-Count; Diagnostic Products, Los Angeles, CA) validated for porcine samples, with intra- and inter-assay coefficients of variation were $7.0 \%$ and $13.5 \%$, respectively, and minimal detectable concentration was $2 \mathrm{ng} / \mathrm{ml}$.

\subsection{Statistical Analysis}

Statistical analyses were performed using SAS (SAS, 2012). All traits were tested for departures from a normal distribution. Natural logarithmic transformation was applied to all traits deviating from a normal distribution. A linear, mixedeffects model was used to analyze all pig variables across weaning ages, piglet variables repeated through the nursery and grow-finish phases, and the effects of age on piglet BW. The pig was the experiment unit. The fixed effects in the model were treatment (age 14 and 28), time $(0,1,7$, and $14 \mathrm{~d}$ post-weaning, and $8,12,16$, and 20 wk-of-age), and sex (gilts and barrows). Random effects included were litter and pen. A repeated measures model with covariance structure was fitted to account for the repeated nature of the measurements within pig. Means and estimate statement are respectively used to compare the effects among different time points and between two weaning age at each time point. Significance was set at $\mathrm{P} \leq 0.05$.

\section{Results}

\subsection{Age Effects on Immune Status}

Prior to weaning ( $0=$ treatment weaning age), total $\mathrm{WBC}$ and lymphocyte counts were greater for 28 -d pigs compared with 14 -d pigs $(\mathrm{P}<0.05$; Table 1$)$ 
and NK cytotoxicity and plasma cortisol concentrations were greater for 28-d pigs when compared with 14 -d pigs $(\mathrm{P}<0.001$; Table 2$)$. Conversely, neutrophil

Table 1. Effects of pig weaning age on total white blood cells, neutrophil (N), lymphocyte (L) populations and $\mathrm{N}: \mathrm{L}$ ratio pre $(\mathrm{d} 0)$ and post (d 1, 7 and 14$)$ weaning.

\begin{tabular}{|c|c|c|c|}
\hline \multirow{2}{*}{ Item } & \multicolumn{2}{|c|}{ Weaning age } & \multirow{2}{*}{$\begin{array}{l}\text { Contrast } \\
14 \text { vs. } 28\end{array}$} \\
\hline & $14 \mathrm{~d}$ & $28 \mathrm{~d}$ & \\
\hline \multicolumn{4}{|l|}{ Total WBC no./mL $\left(10^{8}\right)$} \\
\hline Day 0 , prior to weaning & $1.47 \pm 0.15^{\mathrm{a}}$ & $1.58 \pm 0.15^{\mathrm{a}}$ & * \\
\hline Day 1 , post-weaning & $1.48 \pm 0.15^{\mathrm{a}}$ & $2.00 \pm 0.15^{\mathrm{a}}$ & \\
\hline Day 7, post-weaning & $2.22 \pm 0.16^{\mathrm{b}}$ & $1.71 \pm 0.15^{\mathrm{a}}$ & \\
\hline Day 14 , post-weaning & $1.65 \pm 0.16^{\mathrm{a}}$ & $2.20 \pm 0.15^{\mathrm{b}}$ & $* *$ \\
\hline \multicolumn{4}{|l|}{ Lymphocytes no./mL $\left(10^{7}\right)$} \\
\hline Day 0 , prior to weaning & $2.16 \pm 0.20^{\mathrm{a}}$ & $2.65 \pm 0.20^{\mathrm{a}}$ & * \\
\hline Day 1 , post-weaning & $1.54 \pm 0.20^{\mathrm{b}}$ & $2.86 \pm 0.20^{\mathrm{a}}$ & ** \\
\hline Day 7, post-weaning & $2.38 \pm 0.20^{\mathrm{ac}}$ & $2.93 \pm 0.20^{\mathrm{a}}$ & * \\
\hline Day 14 , post-weaning & $2.73 \pm 0.20^{c}$ & $4.50 \pm 0.20^{\mathrm{b}}$ & $* *$ \\
\hline \multicolumn{4}{|l|}{ Neutrophil no./mL $\left(10^{6}\right)$} \\
\hline Day 0 , prior to weaning & $1.06 \pm 0.26^{\mathrm{a}}$ & $0.85 \pm 0.26^{\mathrm{a}}$ & \\
\hline Day 1 , post-weaning & $1.40 \pm 0.26^{\mathrm{a}}$ & $1.12 \pm 0.26^{\mathrm{ab}}$ & \\
\hline Day 7, post-weaning & $2.51 \pm 0.26^{\mathrm{b}}$ & $1.43 \pm 0.26^{\mathrm{bc}}$ & \\
\hline Day 14 , post-weaning & $1.91 \pm 0.26^{\mathrm{ab}}$ & $1.57 \pm 0.26^{\mathrm{c}}$ & \\
\hline \multicolumn{4}{|l|}{ Lymphocytes, \% } \\
\hline Day 0, prior to weaning & $72.2 \pm 2.1^{\mathrm{a}}$ & $72.7 \pm 1.9^{\mathrm{a}}$ & \\
\hline Day 1 , post-weaning & $60.5 \pm 1.9^{\mathrm{b}}$ & $60.9 \pm 2.0^{\mathrm{b}}$ & \\
\hline Day 7, post-weaning & $49.4 \pm 1.9^{c}$ & $64.3 \pm 1.9^{\mathrm{b}}$ & $* *$ \\
\hline Day 14 , post-weaning & $52.2 \pm 1.9^{c}$ & $67.4 \pm 1.9^{\mathrm{ab}}$ & $* *$ \\
\hline \multicolumn{4}{|l|}{ Neutrophils, \% } \\
\hline Day 0 , prior to weaning & $26.8 \pm 2.1^{\mathrm{a}}$ & $25.4 \pm 1.9^{\mathrm{a}}$ & \\
\hline Day 1 , post-weaning & $36.1 \pm 1.9^{\mathrm{b}}$ & $34.1 \pm 2.0^{\mathrm{b}}$ & \\
\hline Day 7, post-weaning & $45.9 \pm 1.9^{c}$ & $29.5 \pm 1.9^{\mathrm{ab}}$ & $* *$ \\
\hline Day 14 , post-weaning & $41.8 \pm 2.0^{b c}$ & $26.1 \pm 1.9^{\mathrm{a}}$ & $* *$ \\
\hline \multicolumn{4}{|l|}{$\mathrm{N}: \mathrm{L}$ ratio } \\
\hline Day 0, prior to weaning & $0.42 \pm 0.07^{\mathrm{a}}$ & $0.37 \pm 0.07^{\mathrm{a}}$ & \\
\hline Day 1, post-weaning & $0.72 \pm 0.07^{\mathrm{b}}$ & $0.60 \pm 0.07^{\mathrm{b}}$ & \\
\hline Day 7, post-weaning & $1.16 \pm 0.07^{c}$ & $0.51 \pm 0.07^{\mathrm{ab}}$ & $* *$ \\
\hline Day 14 , post-weaning & $0.94 \pm 0.07^{\mathrm{bc}}$ & $0.44 \pm 0.07^{\mathrm{ab}}$ & $* *$ \\
\hline
\end{tabular}

${ }^{\mathrm{a}-\mathrm{c} M e a n s}$ with different superscripts within a column differed at $\mathrm{P}<0.05$ compared to baseline measure (d 0 $=$ prior to weaning). Rows with asterisk (s) represent two means within same row differed at ${ }^{\star} \mathrm{P}<0.05$, or ${ }^{* * \mathrm{P}}<0.001$. 
Table 2. Effects of pig weaning age on innate immunity, immunoglobulin G, and cortisol pre (d 0) and post (d 1, 7 and 14) weaning.

\begin{tabular}{|c|c|c|c|}
\hline \multirow{2}{*}{ Item } & \multicolumn{2}{|c|}{ Weaning age } & \multirow{2}{*}{$\begin{array}{c}\text { Contrast } \\
14 \text { vs. } 28 \mathrm{~d}\end{array}$} \\
\hline & $14 \mathrm{~d}$ & $28 \mathrm{~d}$ & \\
\hline \multicolumn{4}{|l|}{$\begin{array}{l}\text { NK cytotoxicity, } \% \\
(\text { Effector:target }=50: 1)\end{array}$} \\
\hline Day 0 , prior to weaning & $85.0 \pm 6.7^{\mathrm{a}}$ & $54.3 \pm 4.4^{\mathrm{a}}$ & $* *$ \\
\hline Day 1, post-weaning & $70.2 \pm 3.6^{\mathrm{a}}$ & $52.2 \pm 3.7^{\mathrm{a}}$ & \\
\hline Day 7, post-weaning & $58.7 \pm 3.8^{\mathrm{b}}$ & $19.6 \pm 2.9^{\mathrm{b}}$ & \\
\hline Day 14 , post-weaning & $38.9 \pm 2.9^{c}$ & $34.5 \pm 2.8^{\mathrm{c}}$ & \\
\hline \multicolumn{4}{|l|}{ Neutrophil phagocytosis, \% } \\
\hline Day 0, prior to weaning & $33.2 \pm 1.7^{\mathrm{a}}$ & $26.7 \pm 1.7^{\mathrm{a}}$ & $* *$ \\
\hline Day 1 , post-weaning & $44.3 \pm 1.7^{\mathrm{b}}$ & $20.1 \pm 2.7^{\mathrm{a}}$ & \\
\hline Day 7, post-weaning & $32.9 \pm 1.7^{\mathrm{a}}$ & $25.1 \pm 1.7^{\mathrm{a}}$ & \\
\hline Day 14 , post-weaning & $24.7 \pm 1.8^{\mathrm{c}}$ & $32.4 \pm 1.7^{\mathrm{b}}$ & \\
\hline \multicolumn{4}{|l|}{$\begin{array}{l}\text { Neutrophil chemotaxis, no. } \\
\text { (directed migration) }\end{array}$} \\
\hline Day 0 , prior to weaning & $119.8 \pm 18.0^{\mathrm{a}}$ & $96.7 \pm 19.2^{\mathrm{a}}$ & \\
\hline Day 1 , post-weaning & $112.6 \pm 18.1^{\mathrm{a}}$ & $128.1 \pm 18.1^{\mathrm{b}}$ & \\
\hline Day 7, post-weaning & $193.8 \pm 18.1^{\mathrm{b}}$ & $79.6 \pm 18.1^{\mathrm{a}}$ & \\
\hline Day 14 , post-weaning & $115.5 \pm 18.1^{\mathrm{a}}$ & $98.2 \pm 19.1^{\mathrm{a}}$ & \\
\hline \multicolumn{4}{|l|}{ Plasma IgG, ng/ml $\left(10^{3}\right)$} \\
\hline Day 0 , prior to weaning & $4.94 \pm 1.8^{\mathrm{a}}$ & $4.88 \pm 1.8^{\mathrm{a}}$ & \\
\hline Day 1 , post-weaning & $4.25 \pm 1.9^{\mathrm{a}}$ & $4.44 \pm 1.8^{\mathrm{a}}$ & \\
\hline Day 7, post-weaning & $3.29 \pm 1.9^{b}$ & $4.05 \pm 1.8^{\mathrm{a}}$ & \\
\hline Day 14 , post-weaning & $2.68 \pm 1.9^{c}$ & $6.02 \pm 1.9^{\mathrm{b}}$ & $* *$ \\
\hline \multicolumn{4}{|l|}{ Cortisol, ng/ml } \\
\hline Day 0, prior to weaning & $21.8 \pm 2.5$ & $32.9 \pm 2.5^{\mathrm{a}}$ & $* *$ \\
\hline Day 1 , post-weaning & $25.7 \pm 2.5$ & $35.9 \pm 2.5^{\mathrm{ac}}$ & * \\
\hline Day 7, post-weaning & $19.1 \pm 2.6$ & $21.3 \pm 2.5^{\mathrm{b}}$ & \\
\hline Day 14 , post-weaning & $22.1 \pm 2.5$ & $40.0 \pm 2.6^{c}$ & ** \\
\hline
\end{tabular}

${ }^{\mathrm{a}-\mathrm{c} M e a n s}$ with different superscripts within a column differed at $\mathrm{P}<0.05$ relative to baseline value ( $0=$ prior to weaning). Rows with asterisk (s) represent two means within the same row differed at ${ }^{*} \mathrm{P}<0.05$, or ${ }^{* *} \mathrm{P}<0.001$.

phagocytosis was greater for 14 -d pigs compared with 28 -d pigs $(\mathrm{P}<0.001$; Table 2) on d 0 . Pigs weaned at $14 \mathrm{~d}$-of-age had greater total WBC and neutrophil counts on $\mathrm{d} 7$ post-weaning compared with d $0(\mathrm{P}<0.05$; Table 1$)$ and lymphocyte counts and percentages were less on $d 1$ post-weaning compared with $\mathrm{d} 0$, and percentages were still less on $\mathrm{d} 7$ and 14 post-weaning compared with $\mathrm{d} 0$ 
$(\mathrm{P}<0.05$; Table 1). Neutrophil percentages and N:L ratio were greater on $\mathrm{d} 1,7$ and 14 post-weaning compared with $\mathrm{d} 0$ for pigs weaned at $14 \mathrm{~d}$-of-age $(\mathrm{P}<0.05$; Table 1). Conversely, total WBC, lymphocyte, and neutrophil counts were similar for pigs weaned at $28 \mathrm{~d}$-of-age on $\mathrm{d} 1$ and 7 post-weaning compared to $\mathrm{d} 0$ (baseline), but on d 14 post-weaning, total WBC, lymphocyte, and neutrophil counts were greater compared with $\mathrm{d} 0$ and neutrophil percentages and N:L ratio were greater on $\mathrm{d} 1$ post-weaning compared with $\mathrm{d} 0$ for these pigs $(\mathrm{P}<0.05$, Table 1$)$.

Both, 14 and $28 \mathrm{~d}$ weaned pigs had similar NK cytotoxicity on $\mathrm{d} 1$ postweaning compared with $\mathrm{d} 0$, but on $\mathrm{d} 7$ and 14 post-weaning, NK cytotoxicity was less for pigs weaned at $14 \mathrm{~d}$-of-age $(\mathrm{P}<0.001)$ when compared with $\mathrm{d} 0$. On $\mathrm{d} 7$ post-weaning, NK was less for pigs weaned at $28 \mathrm{~d}$-of-age compared with $\mathrm{d} 0$ $(\mathrm{P}<0.001$; Table 2). Neutrophil phagocytosis was greater for pigs weaned at 14 $\mathrm{d}$-of-age on $\mathrm{d} 1$ post-weaning when compared with $\mathrm{d} 0(\mathrm{P}<0.001$; Table 2$)$, but on $\mathrm{d} 14$ post-weaning phagocytosis was less when compared with $\mathrm{d} 0(\mathrm{P}<0.001$; Table 2). Conversely, neutrophil phagocytosis was similar on $\mathrm{d} 1$ and 7 postweaning when compared with $\mathrm{d} 0$ for pigs weaned at $28 \mathrm{~d}$-of-age but on $\mathrm{d} 14$ post-weaning phagocytosis was greater compared with $\mathrm{d} 0(\mathrm{P}<0.01$; Table 2$)$. On $\mathrm{d} 1$ post-weaning neutrophil chemotaxis was greater for pigs weaned at 14 and $28 \mathrm{~d}$-of-age compared to $\mathrm{d} 0$, but less on $\mathrm{d} 7$ and 14 post-weaning for pigs weaned at $14 \mathrm{~d}$-of-age, and less on $\mathrm{d} 14$ post-weaning for pigs weaned at 28 d-of-age $(P<0.05$; Table 2). Total IgG was similar to baseline on $\mathrm{d} 1$ and 7 post-weaning for both 14 and 28 d-of-age weaned pigs, but on $\mathrm{d} 14$ post-weaning those weaned at $14 \mathrm{~d}$-of-age had less total IgG, and pigs weaned at $28 \mathrm{~d}$ had greater IgG when compared with $\mathrm{d} 0(\mathrm{P}<0.05$; Table 2). Cortisol was only affected in those weaned at $28 \mathrm{~d}$-of-age, with cortisol being less on $\mathrm{d} 7$ post-weaning and greater on $\mathrm{d} 14$ for those pigs weaned at $28 \mathrm{~d}$-of-age when compared with $\mathrm{d} 0(\mathrm{P}<0.05$; Table 2$)$.

\subsection{Short-Term: Age Effects on Immune Response to Weaning Stress}

Pigs weaned at $28 \mathrm{~d}$-of-age had greater total WBC $(\mathrm{P}<0.001)$ on d 14 postweaning and greater numbers of lymphocytes $(P<0.01)$ on $\mathrm{d} 1,7$ and 14 postweaning compared with 14-d weaned pigs (Table 1). Pigs weaned at $28 \mathrm{~d}$-of-age had greater lymphocytes \% $(\mathrm{P}<0.001)$ and less neutrophils $(\mathrm{P}<0.001)$ on $\mathrm{d} 7$ and 14 post-weaning compared with 14 -d weaned pigs, resulting in greater $\mathrm{N}: \mathrm{L}$ ratio on $\mathrm{d} 7$ and 14 post-weaning for those 14-d weaned pigs $(\mathrm{P}<0.001$; Table 1). After weaning, plasma IgG was greater on $\mathrm{d} 14$ post-weaning for 28-d weaned pigs compared with pigs weaned at $14 \mathrm{~d}$-of-age $(\mathrm{P}<0.001$; Table 2$)$. On $\mathrm{d} 1$ and 14 post-weaning, cortisol was also greater for pigs weaned at $28 \mathrm{~d}$-of-age compared with $14-\mathrm{d}$ weaned pigs $(\mathrm{P}<0.001$; Table 2$)$.

\subsection{Long-Term: Age Effects on Immune Response to Weaning Stress}

At 8 wk-of-age, total WBC counts $(\mathrm{P}<0.05)$ and at 8,12 , and 20 wk-of age lymphocyte numbers $(\mathrm{P}<0.001)$ were greater for 14 -d weaned pigs compared with 28 -d weaned pigs (Table 3 ). Natural killer cell cytotoxicity was greater at 8 , 
12, 16 and 20 wk-of-age for pigs weaned at $14 \mathrm{~d}$-of-age compared with 28 -d weaned pigs ( $\mathrm{P}<0.001$; Table 4 ) Conversely, at 8 wk-of-age neutrophil phagocytosis $(\mathrm{P}<0.001)$ and at 8 and 12 wk-of-age both neutrophil chemotaxis $(\mathrm{P}<$

Table 3. Effects of pig weaning age on total white blood cells, neutrophil (N), lymphocyte (L) populations and N:L ratio from 8 to 20 weeks of age.

\begin{tabular}{|c|c|c|c|}
\hline & \multicolumn{2}{|c|}{ Weaning age } & \multirow{2}{*}{ P-value } \\
\hline & $14 \mathrm{~d}$ & $28 \mathrm{~d}$ & \\
\hline \multicolumn{4}{|c|}{ Total WBC no./mL $\left(10^{8}\right)$} \\
\hline weeks-of-age & & & $<0.05$ \\
\hline 8 & $2.42 \pm 0.16^{\mathrm{a}}$ & $1.86 \pm 0.15^{\mathrm{b}}$ & \\
\hline 12 & $1.87 \pm 0.16$ & $2.12 \pm 0.15$ & \\
\hline 16 & $2.08 \pm 0.16$ & $2.31 \pm 0.15$ & \\
\hline 20 & $1.59 \pm 0.41$ & $1.86 \pm 0.63$ & \\
\hline \multicolumn{4}{|c|}{ Lymphocytes no./mL $\left(10^{7}\right)$} \\
\hline weeks-of-age & & & $<0.001$ \\
\hline 8 & $5.07 \pm 0.21^{\mathrm{a}}$ & $4.02 \pm 0.20^{\mathrm{b}}$ & \\
\hline 12 & $4.97 \pm 0.21^{\mathrm{a}}$ & $4.05 \pm 0.21^{\mathrm{b}}$ & \\
\hline 16 & $4.17 \pm 0.21$ & $4.46 \pm 0.21$ & \\
\hline 20 & $4.21 \pm 0.21^{\mathrm{a}}$ & $2.13 \pm 0.21^{\mathrm{b}}$ & \\
\hline \multicolumn{4}{|c|}{ Neutrophil no./mL $\left(10^{6}\right)$} \\
\hline weeks-of-age & & & $<0.001$ \\
\hline 8 & $2.67 \pm 0.31$ & $1.83 \pm 0.30$ & \\
\hline 12 & $1.12 \pm 0.31$ & $1.01 \pm 0.30$ & \\
\hline 16 & $1.22 \pm 0.31^{\mathrm{a}}$ & $0.73 \pm 0.30^{\mathrm{b}}$ & \\
\hline 20 & $1.38 \pm 0.27^{\mathrm{b}}$ & $3.25 \pm 0.31^{\mathrm{a}}$ & \\
\hline \multicolumn{4}{|c|}{ Lymphocytes, \% } \\
\hline weeks-of-age & & & $<0.05$ \\
\hline 8 & $62.7 \pm 2.1$ & $65.9 \pm 2.1$ & \\
\hline 12 & $69.7 \pm 2.1$ & $73.2 \pm 2.1$ & \\
\hline 16 & $66.7 \pm 2.1^{\mathrm{b}}$ & $72.4 \pm 2.1^{\mathrm{a}}$ & \\
\hline 20 & $65.4 \pm 2.1$ & $67.5 \pm 2.1$ & \\
\hline \multicolumn{4}{|l|}{ Neutrophils, \% } \\
\hline weeks-of-age & & & $>0.10$ \\
\hline 8 & $30.3 \pm 2.1$ & $29.4 \pm 2.0$ & \\
\hline 12 & $26.3 \pm 2.1$ & $22.5 \pm 2.0$ & \\
\hline 16 & $27.1 \pm 2.1$ & $22.6 \pm 2.0$ & \\
\hline 20 & $29.8 \pm 2.1$ & $28.1 \pm 2.1$ & \\
\hline \multicolumn{4}{|l|}{$\mathrm{N}: \mathrm{L}$ ratio } \\
\hline weeks-of-age & & & $>0.10$ \\
\hline 8 & $0.55 \pm 0.07$ & $0.52 \pm 0.07$ & \\
\hline 12 & $0.41 \pm 0.07$ & $0.33 \pm 0.07$ & \\
\hline 16 & $0.45 \pm 0.07$ & $0.33 \pm 0.07$ & \\
\hline 20 & $0.50 \pm 0.07$ & $0.44 \pm 0.07$ & \\
\hline
\end{tabular}

${ }^{\mathrm{a}, \mathrm{b}}$ Means with different superscripts within a row differed at $\mathrm{P}<0.05$. 
Table 4. Effects of pig weaning age on innate immunity, immunoglobulin G, and cortisol from 8 to 20 weeks of age.

\begin{tabular}{|c|c|c|c|}
\hline & \multicolumn{2}{|c|}{ Weaning age } & \multirow{2}{*}{ P-value } \\
\hline & $14 \mathrm{~d}$ & $28 \mathrm{~d}$ & \\
\hline \multicolumn{4}{|c|}{$\begin{array}{l}\text { NK cytotoxicity, } \% \\
(\text { Effector:target }=50: 1)\end{array}$} \\
\hline weeks of age & & & $<0.001$ \\
\hline 8 & $42.8 \pm 3.1^{\mathrm{a}}$ & $34.9 \pm 3.0^{\mathrm{b}}$ & \\
\hline 12 & $26.9 \pm 3.3^{\mathrm{a}}$ & $17.2 \pm 3.1^{\mathrm{b}}$ & \\
\hline 16 & $30.6 \pm 3.1^{\mathrm{a}}$ & $23.4 \pm 3.1^{\mathrm{b}}$ & \\
\hline 20 & $31.6 \pm 3.2^{\mathrm{a}}$ & $16.8 \pm 3.1^{\mathrm{b}}$ & \\
\hline \multicolumn{4}{|c|}{ Neutrophil phagocytosis, \% } \\
\hline weeks of age & & & $<0.001$ \\
\hline 8 & $19.9 \pm 2.9^{\mathrm{b}}$ & $30.1 \pm 1.6^{\mathrm{a}}$ & \\
\hline 12 & $26.8 \pm 1.7$ & $24.7 \pm 1.7$ & \\
\hline 16 & $20.9 \pm 1.7$ & $19.0 \pm 1.8$ & \\
\hline 20 & $21.4 \pm 1.7$ & $20.3 \pm 1.8$ & \\
\hline \multicolumn{4}{|c|}{$\begin{array}{l}\text { Neutrophil chemotaxis, no. } \\
\text { (directed migration) }\end{array}$} \\
\hline weeks of age & & & $<0.01$ \\
\hline 8 & $123.9 \pm 16.6^{\mathrm{b}}$ & $244.8 \pm 20.8^{\mathrm{a}}$ & \\
\hline 12 & $139.7 \pm 21.1^{\mathrm{b}}$ & $186.3 \pm 19.2^{\mathrm{a}}$ & \\
\hline 16 & $124.2 \pm 21.2$ & $122.2 \pm 22.2$ & \\
\hline 20 & $201.1 \pm 20.8^{\mathrm{a}}$ & $140.4 \pm 19.1^{\mathrm{b}}$ & \\
\hline \multicolumn{4}{|c|}{ Plasma IgG, ng/ml $\left(10^{3}\right)$} \\
\hline weeks of age & & & $<0.05$ \\
\hline 8 & $5.6 \pm 1.9^{\mathrm{b}}$ & $13.0 \pm 1.8^{\mathrm{a}}$ & \\
\hline 12 & $20.9 \pm 2.7$ & $17.8 \pm 2.6$ & \\
\hline 16 & $11.6 \pm 2.8^{\mathrm{b}}$ & $33.3 \pm 3.4^{\mathrm{a}}$ & \\
\hline 20 & $39.7 \pm 2.6^{\mathrm{b}}$ & $48.2 \pm 2.1^{\mathrm{a}}$ & \\
\hline \multicolumn{4}{|c|}{ Plasma cortisol, ng/ml } \\
\hline weeks of age & & & $<0.001$ \\
\hline 8 & $41.7 \pm 2.6$ & $43.8 \pm 2.5$ & \\
\hline 12 & $46.6 \pm 2.5^{\mathrm{a}}$ & $37.5 \pm 2.6^{\mathrm{b}}$ & \\
\hline 16 & $31.9 \pm 2.6$ & $30.1 \pm 2.6$ & \\
\hline 20 & $24.0 \pm 2.6$ & $31.7 \pm 2.5$ & \\
\hline
\end{tabular}

${ }^{\mathrm{a}, \mathrm{b}}$ Means with different superscripts within a row differed at $\mathrm{P}<0.05$.

$0.01)$ and total IgG $(\mathrm{P}<0.05)$ were greater for pigs weaned at $28 \mathrm{~d}$-of-age compared with 14-d weaned pigs (Table 4). At 12-wk-of age cortisol and at 20 
wk-of-age neutrophil chemotaxis were both greater for 14-d weaned pigs (Table $4)$.

\section{Discussion}

These results demonstrate that age at weaning can differentially affect leukocyte populations, innate immune parameters, and total IgG concentrations in response to weaning stress in the short- and long-term. As previously reported, weaning does evoke a stress response as evident by a shift in lymphocytes and neutrophils in the periphery resulting in an elevated neutrophil-to-lymphocyte ratio at $\mathrm{d} 1$ post-weaning, regardless of weaning age. However, this leukocyte shift was short-lived in the 28 - $\mathrm{d}$ weaned pigs because they returned to baseline by day 7 post-weaning. Kick et al [13] also reported similar immunological changes at weaning, but levels returned to baseline 1 wk post-weaning, regardless of weaning age treatment. Conversely, this was not true for those pigs weaned at $14 \mathrm{~d}$-of-age, these pigs actually had a leukocyte profile indicative of prolonged weaning stress. Specifically, the shift in greater neutrophils and less lymphocytes at $\mathrm{d} 7$ and 14 post-weaning in the periphery resulted in significantly elevated N:L ratio in 14-d weaned pigs. Neutrophils proliferate in the periphery in response to stress resulting in neutrophilia which leads to an elevated N:L ratio that is indicative of stress [18] [19]. Stress-induced reduction in circulating lymphocytes is not due primarily to large-scale destruction of cells, but rather to glucocorticoid-induced alterations in the "trafficking", or redistribution, of lymphocytes from the blood to other body compartments [20]. These changes are thought to ensure that the different types of cells are routed to where they are needed during the stress response [18] [21].

Interestingly, the neutrophilia response induced in the 14-d weaned pigs in response to weaning stress was not associated with elevated cortisol, in fact cortisol concentrations remained unchanged in these pigs at 1, 7, and 14 days postweaning and levels were less when compared to pigs weaned at $28 \mathrm{~d}$-of-age. Lack of change in cortisol concentration in response to weaning stress was surprising because increased cortisol is associated with weaning [22], but returns quickly to baseline ( $<7$ days) [13] [14] [23]. Therefore, it is plausible that increased cortisol was not the primary mediator responsible for the shift in leukocyte population profile seen in the 14-d weaned pigs at d 1, 7 and 14 post-weaning. The 28-d weaned pigs were stress as evident by the shift in the leukocyte profile, but this profile was not apparent by $7 \mathrm{~d}$ postweaning; whereas, the 14-d weaned pigs had a more profound response to weaning stress. However, it is apparent despite the leukocyte cell distribution and N:L ratio found in the 14-d weaned pigs being indicative of a stress response to weaning, these changes did not affect the functionality of neutrophils or lymphocytes. Neutrophil phagocytosis and chemotaxis are mechanisms of phagocytic cells, which are essential to host innate defenses against pathogenic microorganisms and neutrophil function was increased at $\mathrm{d} 1$ (phagocytosis) and $\mathrm{d} 7$ (chemotaxis) post-weaning, implying that 14-d weaned 
pigs still had an active innate immune response despite the profound elevated $\mathrm{N}: \mathrm{L}$ ratio at day 7 and 14 post-weaning.

Moreover, long-term elevation of N:L ratio and decreased immune cell numbers occurs when glucocorticoid is chronically elevated and often these changes are not transient or reversed upon cessation of stress [24]. Despite the longlasting elevated N:L ratio seen in the 14-d weaned pigs, cortisol was not chronically elevated and the leukocyte profile was reversed since N:L ratio did not remain elevated and total WBC and lymphocyte numbers were greater by 8 wk-of age. But, neutrophil function may have been affected in the long-term in the 14-d weaned pigs, neutrophil phagocytosis and chemotaxis were less at 8 and 12 wk-of-age compared with 28-d weaned pigs. Moreover, the 14-d weaned pigs had more stimulated NK activity (innate immunity) and less total IgG (adaptive immunity) at $8,12,16$, and 20 wk-of age compared with 28 -d weaned pigs implying that weaning age may have long-term effects on immune response of pigs; with 14-d weaned pigs having greater innate response and 28-d weaned having greater adaptive response. It is plausible that there was a long-term tradeoff in terms of innate immunity among 14-d weaned pigs with reduced neutrophil function for enhance NK cytotoxicity.

The pig is immunologically naive at birth and its immune system usually does not fully develop until about 1 month old [25] [26] [27]. Neonatal animals must rely primarily on their innate immune system until the adaptive immune system develops. Our previous work supports this, as pigs get older both, IgG concentrations and mitogen-induced B-cell proliferation decreased [14] and these findings were similar to findings previously reported [2] [9] [26]. However, in this study, 14-d weaned pigs did not have a more developed adaptive response in the long-term, but a more developed innate response. NK cytotoxicity is an in vitro measure of innate immunity associated with natural killer lymphocyte function and serves as a first-line of nonspecific defense against viral challenges; whereas IgG, an antibody, predominately involved in the secondary antibody response, generally corresponds to maturation of the antibody response. Niekamp et al. [14] found that NK activity was greater in 28-d weaned pigs and activity increased as pigs got older, while Annamalai [28] found that $9 \mathrm{~d}$-of-age suckling pigs had no detectable NK activity, but $26 \mathrm{~d}$-of-age pigs had greater NK activity. Conversely, we found that $14-\mathrm{d}$ weaned pigs baseline was greater but in response to stress was reduced, and still had levels much greater than 28-d weaned pigs at $14 \mathrm{~d}$-of-age through 20 wk-of-age. But, 14-d weaned pigs had much lower IgG at 20 wk-of-age. These findings contradict our earlier findings [14], but these differences may be partly attributed to the differences between this study and previous work, especially in terms of lack of photoperiodic treatment, different blood sampling schedule, and longer duration of this study. But, it is also plausible that the profound leukocyte profile seen in the 14-d weaned pigs within contributed to this skewed innate profile. Regardless of the explanation, it is apparent those pigs weaned at $14 \mathrm{~d}$-of-age had a more active innate 
immune response (NK activity) in the long-term; whereas, 28-d weaned pigs had a more robust humoral response.

\section{Conclusion}

In summary, weaning at either 14 or $28 \mathrm{~d}$-of-age was a stressful event, and immunological changes were observed both short- and long-term. Immunological differences shortly after weaning were more robust and longer-lasting in pigs that were weaned at $14 \mathrm{~d}$-of-age. These pigs had more profound stress response to weaning in terms of changes in leukocyte populations, neutrophil function, and NK activity at 7 and $14 \mathrm{~d}$ post-weaning; whereas late weaned pigs returned to baseline for all parameters by $\mathrm{d} 7$ post-weaning. Moreover, this study demonstrated that age at weaning and stress response to weaning differentially affected innate immunity and antibody production long-term; with the 14-d weaned pigs had more activated NK activity at 20 wk-of-age while the 28 -d weaned pigs had more activated IgG response. Thus, age at weaning may have long-term effects on pig immune status.

\section{Acknowledgements}

This research was supported by the Animal Health and Disease (Section 1433) The Illinois Agricultural Experiment Station (USDA, CSRS). The authors thank Dr. Sandra Rodriguez-Zas for statistical advice and assistance.

\section{References}

[1] Salak-Johnson, J.L. and McGlone, J.J. (2007) Making Sense of Apparently Conflicting Data: Stress and Immunity in Swine and Cattle. Journal of Animal Science, 85, E81-E88. https://doi.org/10.2527/jas.2006-538

[2] Hoskinson, C.D., Chew, B.P. and Wong, T.S. (1990) Age-Related Changes in Mitogen-Induced Lymphocyte Proliferation and Polymorphnuclear Neutrophil Function in Piglet. Journal of Animal Science, 68, 2471-2478. https://doi.org/10.2527/1990.6882471x

[3] Kattesh, H.G., Charles, S.F., Baumbach, G.A. and Gillespie, B.E. (1990) Plasma Cortisol Distribution in the Pig from Birth to Six Weeks of Age. Biology Neonate, 58, 220-226. https://doi.org/10.1159/000243271

[4] Bianchi, A.T.J., Moonen-Leusen, H.W.M., van der Heijden, P.J. and Bokhout, B.A. (1995) The Use of a Double Antibody Sandwich ELISA and Monoclonal Antibodies for the Assessment of Porcine IgM, IgG and IgA Concentrations. Veterinary Immunology and Immunopathology, 44, 309-317. https://doi.org/10.1016/0165-2427(94)05307-E

[5] Deprez, P., Van de Hende, C., Muylle, E. and Oyaert, W. (1986) The Influence of the Administration of Sow's Milk on the Post-Weaning Excretion of Hemolytic E. Coli in the Pig. Veterinary Research Communication, 10, 469-478. https://doi.org/10.1007/BF02214010

[6] Smith, F., Clark, J.E., Overman, B.L., Tozel, C.C., Huang, J.H., Rivier, J.E., Blikslager, T. and Moeser, A.J. (2010) Early Weaning Stress Impairs Development of $\mathrm{Mu}$ cosal Barrier Function in the Porcine Intestine. American Journal of Physiology Gastrointestinal and Liver Physiology, 298, G353-G363. 
https://doi.org/10.1152/ajpgi.00081.2009

[7] McLamb, B.L., Gibson, A.J., Overman, E.L., Stahl, C. and Moeser, A.J. (2013) Early Weaning Stress in Pigs Impairs Innate Mucosal Immune Responses to Enterotoxigenic E. coli Challenge and Exacerbates Intestinal Injury and Clinical Disease. PloS One, 8, e59838. https://doi.org/10.1371/journal.pone.0059838

[8] Metz and Gonyou, H.W. (1990) Effect of Age and Housing Conditions on the Behavioral and Hemolytic Reaction of Piglets to Weaning. Applied Animal Behaviour Science, 27, 299-309. https://doi.org/10.1016/0168-1591(90)90126-X

[9] Blecha, F., Pollman, S. and Nichols, D.A. (1983) Weaning Pigs at an Early Age Decreases Cellular Immunity. Journal of Animal Science, 56, 396-400.

https://doi.org/10.2527/jas1983.562396x

[10] Bailey, M., Clarke, C.J., Wilson, A.D., Williams, N.A. and Stokes, C.R. (1992) Depressed Potential for Interleukin-2 Production Following Early Weaning of Piglets. Veterinary Immunology Immunophathology, 34, 197-207. https://doi.org/10.1016/0165-2427(92)90164-L

[11] Kanitz, E., Tuchscherer, M., Tuchscherer, A., Stabenow, B. and Manteuffel, G. (2002) Neuroendocrine and Immune Response to Acute Endotoxemia in Suckling Piglets. Neonatology, 81, 203-209. https://doi.org/10.1159/000051535

[12] Davis, M.E., Sears, S.C., Apple, J.K., Maxwell, C.V. and Johnson, Z.B. (2006) Effect of Weaning Age and Commingling after the Nursery Phase of Pigs in a Wean-to-Finish Facility of Growth, and Humoral and Behavioral Indicators of Well-Being. Journal of Animal Science, 84, 743-756. https://doi.org/10.2527/2006.843743x

[13] Kick, A.R., Tompkins, M.B., Flowers, W.L., Whisnant, C.S. and Almond, G.W. (2012) Effects of Stress Associated with Weaning on Adaptive Immune System in Pigs. Journal of Animal Science, 90, 649-656. https://doi.org/10.2527/jas.2010-3470

[14] Niekamp, S.R., Sutherland, M.A., Dahl, G.E. and Salak-Johnson, J.L. (2007) Immune Responses of Piglets to Weaning Stress: Impacts of Photoperiod. Journal of Animal Science, 85, 93-100. https://doi.org/10.2527/jas.2006-153

[15] Sutherland, M.A., Rodriguez-Zas, S.L., Ellis, M. and Salak-Johnson, J.L. (2005) Breed and Age Affect Baseline Immune Traits, Cortisol, and Performance in Growing Pigs. Journal of Animal Science, 83, 2087-2095. https://doi.org/10.2527/2005.8392087x

[16] Salak, J.L., McGlone, J.J. and Lyte, M. (1993) Effects of in Vitro Adrenocorticotrophic Hormone, Cortisol, and Human Recombinant Interleukin-2 on Porcine Neutrophil Migration and Luminal-Dependent Chemiluminescence. Veterinary Immunology and Immunopathology, 39, 327-337. https://doi.org/10.1016/0165-2427(93)90065-C

[17] Jolie, R., Backstrom, L., Olson, L. and Chase, C. (1999) Respiratory and Systemic Health Parameters in Pigs Raised in a Conventional Farm or in Isolation. Swine Health and Production, 7, 269-275.

[18] Dhabhar, F.S., Miller, A.H., McEwen, B.S. and Spencer, R.L. (1996) Stress-Induced Changes in Blood Leukocyte Distribution: Role of Adrenal Steroid Hormones. Journal of Immunology, 157, 1638-1644.

[19] Davis, A.K., Maney D.L. and Maerz, J.C. (2008) The Use of Leukocyte Profiles to Measure Stress in Vertebrates: A Review for Ecologists. Functional Ecology, 22, 760-772. https://doi.org/10.1111/j.1365-2435.2008.01467.x

[20] Dhabhar, F.S. (2002) A Hassle a Day May Keep the Doctor Away: Stress and the 
Augmentation of Immune Function. Integrative and Comparative Biology, 42, 556-564. https://doi.org/10.1093/icb/42.3.556

[21] Dhabhar, F.S., Miller, A.H., Stein, M., McEwen, B.S. and Spencer, R.L. (1994) Diurnal and Acute Stress-Induced Changes in Distribution of Peripheral Blood Leukocyte Subpopulations. Brain, Behavior and Immunity, 8, 66-79.

https://doi.org/10.1006/brbi.1994.1006

[22] Kojima, C.J., Kattesh, H.G., Roberts, M.P. and Sun, T. (2008) Physiological and Immunological Responses to Weaning and Transport in the Young Pig: Modulation by Administration of Porcine Somatotropin. Journal of Animal Science, 86, 2913-2919. https://doi.org/10.2527/jas.2008-1089

[23] Tuchscherer, M., Kanitz, E., Puppe, B., Tuchscherer, A. and Viergutz, T. (2009) Changes in Endocrine and Immune Responses of Neonatal Pigs Exposed to Psychosocial Stressor. Research Veterinary Science, 87, 380-388.

https://doi.org/10.1016/j.rvsc.2009.04.010

[24] Dhabhar, F.S. (2009) Enhancing versus Suppressive Effects of Stress on Immune Function: Implications for Immunoprotection and Immunopathology. Neuroimmunomodulation, 16, 300-317. https://doi.org/10.1159/000216188

[25] Kim, Y.B. (1975) Developmental Immunity in the Piglet. Birth Defects Original Article Series, 11, 549-557.

[26] McCauley, I. and Hartmann, P.E. (1984) Changes in the Proportion and Absolute Number of T Lymphocytes in Piglets from Birth until after Weaning and in Adults. Research in Veterinary Science, 37, 52-57.

[27] McCauley, I. and Hartmann, P.E. (1984) Changes in Piglet Leucocytes, B Lymphocytes and Plasma Cortisol from Birth to Three Weeks after Weaning. Research in Veterinary Science, 37, 234-241.

[28] Annamalai, T., Saif, L.J., Lu, Z.Y. and Jung, K. (2015) Age-Dependent Variation in Immune Responses to Porcine Epidemic Diarrhea Virus Infection in Sucking versus Weaned Pigs. Veterinary Immunology and Immunopathology, 168, 193-202. https://doi.org/10.1016/j.vetimm.2015.09.006 